\title{
Anmeldelse
}

\section{Dansk Sproghistorie. Bind 1: Dansk tager form.}

Udgivet af Det danske Sprog- og Litteraturselskab. Hovedredaktør: Ebba Hjorth. Øvrige redaktører: Henrik Galberg Jacobsen, Bent Jørgensen, Birgitte Jacobsen og Laurids Kristian Fahl. Aarhus Universitetsforlag. 472 sider.

\section{ASGERD GUDIKSEN}

\section{INDLEDENDE PRÆSENTATION}

Den 11. november 2016 udkom bind 1 af Dansk Sproghistorie, en begivenhed der har været afventet med vis spænding blandt mange sproginteresserede. Det bliver et værk i seks bind, og 87 forfattere har medvirket. Det er altså ikke et projekt som man lige gør om igen, og et værk der gerne skulle kunne være til nytte og glæde i mange år. Det store arbejde skulle også gerne resultere $i$ et supplement og en opdatering $i$ forhold til Peter Skautrups Det danske Sprogs historie (1944-1970). Endnu er spændingen langt fra udløst. Første bind er nemlig lidt atypisk ved at ca. to tredjedel består af indledende og forskningshistoriske kapitler, mens resten af bindet beskriver skriftens historie. Hvordan selve sprogbeskrivelserne bliver, må vi altså vente med at få svar på et stykke tid endnu.

Dansk Sproghistories overordnede inddeling er som antydet tematisk i modsætning til Skautrups sproghistorie, hvor hovedinddelingen er baseret på sproghistoriske perioder (urnordisk, olddansk osv.). Indholdet af de øvrige bind er omtalt i forordet. Bind 2, Ord for Ord for Ord, og bind 3, Bøjning og Bygning, vil beskæftige sig med ortografi, tegnsætning, udtale, bøjning og syntaks, kort sagt udviklingen af de sproglige elementer. Bind 4, Dansk i brug, drejer sig om dansk i forskellige sproggenrer, fx lovsprog, bibelsprog, mediesprog og afrundes med afsnit om læse- og skrivefærdighed, normering og dansk som andetsprog. Bind 5, Dansk i samspil, beskæftiger sig dels med dansk uden for Danmark, dels med "Andre sprog i Danmark" (s. 12) før og nu, og endelig bind 
6, Forfatternes sprog, kommer til at indeholde karakteristik af 20 forfatteres sprog på baggrund af indledende kapitler om "Sprog og stil" (s. 13). Man kan også se en oversigt over værkets disposition, kapitelinddeling og forfattere på Det Danske Sprog- og Litteraturselskabs hjemmeside https://dsl.dk/sprog/sprogets-historie/dansk-sproghistorie, så jeg skal ikke gå i detaljer, men kun bemærke at værket altså ikke kun kommer til at beskæftige sig med sproget, det danske sprogs historie, men også sprogsamfundets, noget Skautrup også inddrog. Man noterer sig også at Dansk Sproghistorie viderefører traditionen for en grundig beskrivelse af udvalgte forfatteres sprog, og at der også ser ud til at være nye emneområder. Der er kort sagt meget og meget forskelligt at være spændt på. Men tilbage til det der faktisk foreligger: bind 1, hvis indhold som nævnt afviger temmelig meget fra traditionen inden for dansk sproghistorieskrivning med sit fokus på forskningshistorie.

Bind 1 - og hele værket - indledes med to forord, Selskabets forord (dvs. Det Danske Sprog- og Litteraturselskabs) og et forord af hovedredaktøren, Ebba Hjorth. Selskabet fremhæver (s. 7) selskabets grundholdning: at videnskabelighed og folkeoplysning ikke er hinandens modsætninger, men tværtimod bør gå hånd i hånd. Og Ebba Hjorth skriver tilsvarende at den nye sproghistorie er "til brug for såvel alment sproginteresserede som forskere" (s. 10), men tilføjer dog også at: "de mange forskellige emner der behandles kræver [...] vidt forskellige forudsætninger af læseren. Ikke alle vil blive lige fascineret af de mange discipliner der behandles”. Det viser sig allerede i det første bind. Nogle af afsnittene er givetvis mere let tilgængelige end andre, men der er tydeligvis lagt et stort arbejde med fremstillingens form både af forfatterne og redaktørerne - og med at understøtte teksten med billeder og figurer.

Bind 1 har undertitlen Dansk tager form. Titlen dækker kun en lille del af indholdet, men det ville nok være næsten umuligt at finde en titel der kunne dxkker de ret forskelligartede bidrag. Bindet har dog med en lidt god vilje kunnet samles i fire hovedkapitler: 1. Kilderne, 2. Historie og Sprog, 3. Sprogbeskrivelser og 4. Skrift. Jeg vil her koncentrere mig om de tre første hovedkapitler der nok især har relevans for den typiske 
læser af NyS, mens det sidste hovedkapitel om skriftens historie kun vil blive kort omtalt.

Bindet afsluttes med en samlet litteraturliste, billedoplysninger, oplysninger om forfattere og redaktører. Oplysningerne om redaktørerne er biografiske noter på 8-10 linjer, om forfatterne oplyses derimod kun titel, alder og ansættelsessted. Lidt fyldigere omtale kunne i nogle tilfælde have været nyttig, selv om mange af forfatterne sikkert er kendt af læsere der er optaget af sprog og sprogforskning. Endelig er der en oversigt over en nyskabelse, som Skautrup af gode grunde ikke havde med, nemlig en fortegnelse over det supplerende materiale der ligger frit tilgængeligt på hjemmesiden http://www.dansksproghistorie.dk.

Der er rundt regnet tre typer supplerende materiale: supplerende tekstmateriale udarbejdet af forfatteren, henvisninger til uddybende oplysninger på nettet (næsten kun Det Danske Sprog- og Litteraturselskabs hjemmesider, https://dsl.dk) og - i få tilfælde - lyd- eller filmklip, bl.a. lydoptagelsen af skuespillerinden Louise Phister født 1816 (også en af kilderne til Brink og Lund 1975). Det er dog kun enkelte af forfatterne til bind 1 der har udnyttet denne mulighed i større stil. I det hele taget har forfatterne ikke været holdt i kort snor. Det fremgår også af Ebba Hjorths forord hvor hun kort kommer ind på hvordan værket er blevet til:

De mange forfattere med deres forskellige baggrunde har bidraget til værket ud fra forskelligt sprogsyn og forskellig opfattelse af hvordan god formidling og gedigen videnskab arbejder sammen. Alle forfatternes kapitler har været underlagt redaktionel bearbejdelse uden at det nødvendigvis i alle tilfælde afspejler fuld faglig enighed mellem forfattere og redaktionen. Det har ikke været hensigten og heller ikke muligt at ensrette de mange forfatteres behandling af deres emne (s. 10).

\section{KAPITEL 2. HISTORIE OG SPROG}

Dansk tager form begynder med et ret kort kapitel om kilderne (s. 17-30) af Bent Jørgensen, en af værkets redaktører, med hovedvægten lagt på en oversigt over de middelalderlige kilder. Derefter følger det omfat- 
tende kapitel Historie og Sprog med fem meget forskelligartede underkapitler, både hvad angår synsvinkel og form.

Frans Gregersen lægger for med et vægtigt underkapitel Sproghistorie og sprogteori (s. 35-77). Hovedparten af kapitlet udgøres af en skildring af sprogvidenskabens historie i Danmark med den samtidige internationale sprogforskning som baggrund. Frans Gregersen diskuterer også spørgsmål som hvad er sproghistorie?, hvornår begynder sprogvidenskaben?, hvordan kan sprogvidenskaben opdeles i epoker?, og hvilke begivenheder er så skelsættende at man kan sige at noget nyt begynder og hvorfor? Det er et stort og komplekst emne, men det lykkes at give læseren forstålse for hvordan sprogteori og opfattelsen af sprogforandring hænger sammen, og hvilke erkendelsesinteresser der driver 1800-tallets historisme og 1900-tallets strukturalisme og sociolingvistik.

Bent Jørgensen står også for to kapitler i Historie og Sprog. Kapitlet Sproghistoriske perioder (79-83) præsenterer Dansk Sproghistories periodeinddeling på baggrund af en nyttig gennemgang af periodeinddelinger og periodebetegnelser i dansk sproghistorisk litteratur, der også demonstrerer klart at periodeinddeling ikke er noget givet, men afhænger af beskrivelsens formål og sprogsyn. Kapitlet Sproghistorier og andre historier (s. 157-188) er umiddelbart ikke helt let at overskue. Årsagen er bl.a. at kapitlet er opdelt i mindre afsnit der går på tværs af forfatterens disposition. Kapitlet viser sig at indeholde fem "historier". Det indeholder if. forordet (s. 11) "enkeltfortællinger om sproget som kilde til en lang række historiske forhold", men giver imidlertid i lige så høj grad eksempler på hvordan ændringer i samfund og samfundsinstitutioner virker ind på sprogbrug og ordforråd. Tre af historierne drejer sig om udviklingen inden for kirke, retsvæsen og administration i middelalderen mht. brug af skrift og sprog (dansk vs. latin eller nedertysk), den fjerde om hvordan øget professionalisering af håndværkene medfører stor vækst af ordforrådet inden dette domæne, og den femte om hvordan samfundsudviklingen afspejles i brugen af erhvervsbetegnelser om kvinder. Det bedste ved kapitlet er de interessante eksempler, ikke mindst lærerige er eksemplerne på hvor vanskeligt det kan være at finde ud af hvad et ord der optræder i gammeldanske kilder, betyder, 
og hvor usikkert det ofte kan være hvad datidens mennesker kaldte de genstande arkæologerne finder.

Esben Albrechtsens kapitel har titlen Sprog og Identitet (s. 85-123) og handler mere præcist om hvilken betydning det danske sprog har haft for national identitet, og hvad bevidstheden om at være dansker er baseret på og ikke mindst har været baseret på. Der er flere opfattelser af hvornår der opstår en national identitet, der kan sammenfattes i to hovedsynspunkter, skriver Albrechtsen (s. 121). Det ene siger at der er tale om et nyere fænomen opstået i slutningen af 1700-tallet, det andet at national identitet har været der "hele tiden", men vækkes af nationalromantikken. Esben Albrechtsen tilslutter sig den sidste opfattelse - og begynder derfor med de forestillinger der kommer udtryk i Valdemartidens historieskrivning fra 1200-tallet (bl.a. Saxo). Det er dog formentlig først fra midten af 1800-tallet at national identifikation med stor sikkerhed kan anses for et massefænomen, understreger han dog også (s. 121), ligesom han flere steder gør opmærksom på de grænser kildematerialet sætter, bl.a. at vi indtil den nyeste tid ingen direkte vidnesbyrd har om hvordan "almindelige mennesker" opfattede deres tilhørsforhold. Kort sagt er der tale om en nuanceret, velunderbygget fremstilling, der også opsummeres fint til sidst.

Adam Hyllesteds kapitel Sprogfamilien (125-155) hører til dels også hjemme blandt sprogbeskrivelserne i de kommende bind, især den afsluttende del af kapitlet der gennemgår en række fællesnordiske eller østnordiske lydlige og morfologiske ændringer, illustreret med eksempler på følgerne af dem i moderne dansk standardsprog eller (sjældnere) dialektalt. Mens Frans Gregersen beskriver den sammenlignende sprogvidenskabs teorier, fremlægger Adam Hyllested dens resultater. Der er naturligvis meget klassisk stof der også optræder hos fx Skautrup: den indoeuropæiske sprogfamilie, den germanske lydforskydning osv., men kapitlet inddrager $\mathrm{i}$ høj grad ny viden inden for forskningsfeltet, $\mathrm{fx}$ problematiseringen af den traditionelle opdeling i østnordisk og vestnordisk (s. 130). Ikke mindst udnytter Adam Hyllested de senere års forskning inden for indoeuropæistik. Og så er det hele pædagogisk forklaret, også det mere tekniske som fx hvad en rekonstrueret form er, og hvordan man når frem til den (s. 127). 
Kapitlerne i Historie og Sprog fremstår som sagt forskelligartede. Men der er også temaer der er fælles for to eller flere af bidragene. Normalt virker det imidlertid ikke som en trættende gentagelse, men som en udvidelse. Det er fx interessant at sammenligne lingvistens Frans Gregersens diskussion af 1800-tallets historisme, og historikeren Esben Albrechtsens diskussion af "modersmålet som national markør" i samme periode eller Gregersens og Hyllesteds beskrivelse af den sammenlignende sprogvidenskabs metoder.

\section{KAPITEL 3. SPROGBESKRIVELSER}

Det tredje hovedkapitel i bind 1 har titlen Sprogbeskrivelser. Sprogbeskrivelser har her konkret betydning bog (værk, afhandling) der beskriver sprog. Kapitlet er med andre ord et forskningshistorisk kapitel hvor kapitlets fem forfattere har til opgave at give oversigt over litteraturen inden et forskningsområde på et begrænset antal sider. Alt kan umuligt komme med, og forfatteren må derfor prioritere om der skal være lidt om meget eller meget om lidt. At forfatterne har haft metodefrihed, fremgår også tydeligt af dette kapitel.

Ebba Hjorths kapitel Ordboger (s. 209-234) er disponeret som kronologiske beskrivelser af enkeltværker der repræsenterer "vigtige skridt i ordbogsgenrens historiske udvikling" (s. 209), præsentationer der nærmer sig leksikonartikler. De enkelte ordbøgers historie ridses op, ordbogen karakteriseres leksikografisk (hvor mange oplysningstyper indeholder ordbogen, hvilke type ordbog er der tale om o.l.), og endelig vurderes ordbogen, for de ældstes vedkommende især som sproghistorisk kilde. I et par tilfælde virker vurderingen lidt skæv. Ordbog over det danske sprog karakteriseres ganske vist som en "bedrift" (s. 226), men det kommer til at fremstå som et postulat, fordi omtalen især dvæler ved værkets svagheder. Til gengæld kan den lille Gade/dansk. En ordbog over ghettodansk på 450 opslagsord (Borup \& Sufi 2014) næppe leve op til karakteristikken i Dansk Sproghistorie (s. 233), hvor den nærmest præsenteres som en korpusbaseret, professionel ordbog. Det er den ikke, den er en sympatisk amatørordbog med vist overvejende konstruerede eksempler. Man kan derfor også undre sig lidt over at den er blevet udvalgt til omtale på den forholdsvis begrænsede plads. Hovedvægten er 
ellers historisk. Før 1600 er medtaget hvad der findes (seks tosprogede ordbøger til hjælp ved læsning og skrivning på latin). Når det gælder nyere tid, koncentrerer Ebba Hjorth sig især om modermålsordbøgerne, men enkelte andre ordbøger får også en omtale bl.a. Begrebsordbogen (udgivet af Det danske Sprog- og Litteraturselskab) og altså Gade/ dansk. Dialektordbøger er omtalt kort i en faktaboks. Det samme gælder historiske ordbøger, bortset fra Gammeldansk Ordbog, der er udvalgt til nærmere omtale. Ebba Hjorth er en af de forfattere der i høj grad udnytter muligheden for at bringe ekstramateriale, især af i form af henvisninger til Det danske Sprog- og Litteraturselskabs hjemmeside, hvor de fleste af de omtalte ordbøger er publiceret i elektronisk form.

I kapitlet Grammatikeker (s. 235-256) har Lars Heltoft valgt at bygge kapitlet op omkring seks centrale grammatikker med Paul Diderichsens Elementar dansk Grammatik som udgangspunkt for fremstillingen og det arbejde som de øvrige grammatikker holdes op imod. Fokus er lagt på Diderichsens sætningsskema, hans mest betydningsfulde og indflydelsesrige bidrag til den grammatiske beskrivelse. Med udgangspunkt i konkrete sætningseksempler forklarer Lars Heltoft hvad sætningsskemaet er, hvad man opnår ved at inddrage skemaet $\mathrm{i}$ analysen, og hvor Diderichsen hentede inspirationen til sin grammatiske beskrivelse. Derefter følger to længere karakteristikker af henholdsvis Mikkelsens "vigtigste bidrag til den systematiske grammatik" (s. 247) (nemlig hans sætningstypologi hvor der skelnes ubestemte sætninger og sætninger der tager udgangspunkt i "ting" eller "virksomheder), og Aage Hansens "vigtigste bidrag til ledstillingslæren" (s. 248), der dog kritiseres på flere punkter. Derpå kommer et afsnit om Den generative grammatiks reception af sætningsskemaet" (s. 250) (lidt komprimeret og indforstået), og afsnit der giver eksempler på udnyttelsen af Diderichsens sætningsskema i lærebøger og referencegrammatikker. Heltoft afslutter kapitlet med de revisioner af Diderichsens sætningsskema der fremlægges i Grammatik over det danske Sprog, den omfattende grammatik han udgav sammen med Erik Hansen i 2011 (Hansen og Heltoft 2011). Kapitlet indeholder altså ikke en egentlig oversigt over grammatikskrivningens historie. Til gengæld giver kapitlet god forståelse af udvalgte centrale aspekter inden for syntaksforskningen i det 20 . århundrede. 
Heller ikke Henrik Galberg-Jacobsens kapitel Retskrivningshåndbøger (s. 257-277) er disponeret kronologisk. Retskrivningshåndbøger er et overbegreb for "retskrivningslærer" og "retskrivningsordbøger", og kapitlet indledes med afklaring af de to genrer. Resten af kapitlet består $i$ en gennemgang af principper for retskrivningsnormering med eksempler på hvad princippet består $\mathrm{i}$, og hvilke konsekvenser det kan have, fx det fonetiske princip, det pædagogiske princip og, det etymologiske. Under gennemgangen omtales også hvilken rolle disse principper har spillet $\mathrm{i}$ forskellige retskrivningslærer i tidens løb, og hvordan de har indgået i normeringsdiskussioner. I afsnittet om det lydlige princip omtales fx Rasmus Rasks retskrivningslære (1826), og under fordanskningsprincippet kan man bl.a. læse om Peder Syvs ideer fra 1600-tallet og om majonæsekrigen i 1986. Gennemgangen af retskrivningsprincipper er suppleret med et nyttigt kronologisk skema (s. 259) over de 14 vigtigste retskrivningsnormer hvor der angives hvor normen er udformet, af hvem, dens udbredelse og grundlæggende principper. Fx:

Molbechs retskrivning (1815). Privat, traditionel norm udformet i retskrivningsordbogen Dansk. Haand-Ordbog (1815) [...]. Officiel skolenorm fra 1847 og den bredt accepterede norm det meste af 1800-tallet.

Kombinationen af den tematiske gennemgang og det kronologiske skema fungerer godt formidlingsmæssigt. Læseren får både overblik og forståelse for de valg og vanskeligheder der ligger i retskrivningsnormering. Skemaet ligger i udvidet form på hjemmesiden.

Hans Basbølls kapitel Fonetikker (s. 279-297) falder i to afdelinger. Den første er en historisk gennemgang af tidlige beskrivelser af dansk udtale fra Jacob Madsen (1586) til 1900. Den giver en forholdsvis detaljeret omtale af de enkeltes bidrag med eksempler på sproglige iagttagelser de ældre fonetikere har gjort, undertiden overraskende moderne. Det gælder selvfølgelig særligt Høysgaard (1698-1773), der da også får en mere grundig beskrivelse uddybet med to instruktive figurer der viser henholdsvis hans modeller for vokalsystemet og prosodien forsynet med de tilsvarende moderne termer. I det hele taget er der gjort en god indsat for at få formidlet det ret tekniske stof $\mathrm{i}$ afsnittet til 
en lidt bredere kreds ved hjælp af figurer og faktabokse. Meget nyttig er også en figur over "lumske ligheder" mellem IPA og Dania (s. 290) både for IPA- og Daniatilhængere. Formidlingsmæssigt er det lidt uheldigt at figuren over Høysgaards prosodi (s. 285) er forsynet med den terminologi Høysgaard når frem til i 1769, mens brødteksten (med eksempler på de enkelte ordtyper) samme side citerer hans version fra 1743. Efter 1900 - hvor litteraturen vokser - er fremstillingen grupperet efter "skoler", og mere summarisk. Der er fx et afsnit om Otto Jespersens fonetik og de der i nyere tid er inspireret af ham (fx Brink og Lund 1975), om Poul Andersen og andre strukturalistisk orienterede dialektforskere, og om Eli Fischer-Jørgensen og hendes kolleger og elever (hvor Basbøll selv figurerer). Teksten i bogen er imidlertid suppleret med en række nyttige oversigtsskemaer på hjemmesiden: Nogle fonologiske analyser efter 1900 af rigsmålets vokalsystem, konsonantsystem, stødsystem og tryksystem. På hjemmesiden finder man også en udvidet version af faktaboksen "Dansk Rigsmål - definition" med en vigtig tilføjelse, der underbygger indtrykket af at Hans Basbøll har fundet det vanskeligt at få plads til det hele på de tildelte sider.

Bente Holmbergs kapitel Sproghistorier (s. 193) indledes med nogle bemærkninger om hvad disciplinen sproghistorie beskæftiger sig med. Derimod er der ikke en definition af genren sproghistorie, og det kan være medvirkende til at kapitlet ind i mellem taber fokus. Noget af stoffet er allerede foregrebet i Frans Gregersen beretning, men kapitlet supplerer med en mere detaljeret oversigt over sproghistorisk litteratur, herunder synspunkter på de centrale sproghistoriske spørgsmål: hvad er det nordiske grundsprog, og hvornår opstår der et standardsprog. Kapitlet afsluttes med en kort beskrivelse af vigtige sproghistoriske værker. Der er imidlertid også afsnit der ikke drejer sig om sproghistorieskrivning i snævrere forstand, afsnit om ordbøger, tekstudgivelse og dialektforskningen der behandles andre steder i Dansk Sproghistorie, og derfor kunne undværes her. Det gælder især den noget ubalancerede oversigt over dialektforskningens historie. Størstedelen handler om KJ. Lyngby (1829-1871), derefter er der nogle få linjer om strukturalismen (der normalt ikke beskæftiger sig med den historiske dimension) og om Kort over danske Folkemål (Bennike \& Kristensen 1898-1912). Bente Holmbergs kapitel er en oversættelse og let opdateret version af hendes 
forskningsoversigt "Reseach in Danish language history 1850-1950" (i Bandle m.fl. 2002-2005:68-75), hvilket burde have været angivet. Det er også lidt underligt at fremstillingen ikke er blevet justeret i forhold til den aktuelle sammenhæng. Ved at udelade noget af stoffet kunne omtalen af centrale værker, bl.a. Skautrup, være blevet uddybet. Bente Holmbergs korte karakteristik (s. 206) ender således: For beskrivelsen af sprogsystemet (dvs. "ortografi, lyd, bøjning, syntaks m.m." ") er den stærke kobling mellem sprog og samfund dog mere en belastning end en fordel". Det synspunkt havde man gerne set uddybet.

Som sagt: det er en vanskelig opgave forfatterne til kapitel 3 er blevet tildelt, men de har hver på deres måde nået frem til en læseværdig løsning. Kapitlet har dog ikke overflødiggjort de forskningsoversigter som er udgivet af Selskab for Nordisk Filologi (spec. Larsen m.fl. 1965 og Holmberg m.fl. 1989) - med den begrænsning bøgernes udgivelsesår sætter - et synspunkt forfatterne formentlig vil dele eftersom der henvises til bøgerne flere steder i kapitlet, og de omtales samlet i slutningen af Bente Holmbergs afsnit.

\section{AFSLUTNING}

Bind 1 afsluttes med en grundig gennemgang af skriftens historie $i$ Danmark (s. 301-435) fra de første runealfabeter omkring år 200 til skrifttegn på computere omkring 2000, med kapitler om bl.a. skrift i middelalderhånskrifter, nyere tids håndskrift, trykkeskrift, stenografi og blindeskrift. Og der er som i de øvrige afsnit tale om formidlende fremstilling, der virker pålidelig, og som er støttet af gode illustrationer. Man kan dog diskutere, synes jeg, om skriftens historie hører med til en sproghistorie, og om de mange sider om skriften hellere skulle have været brugt til at give mere plads til andet stof. Det vil vise sig. Samtidig er der næppe tvivl om at der er mange læsere der vil finde oplysninger af interesse også i dette kapitel. Jeg selv synes fx det var morsomt at få noget at vide stenografiens historie, som jeg ikke har skænket en tanke før. Hvordan den tematiske opdeling vil fungere, og hvordan de forskningshistoriske afsnit vil spille sammen med de følgende bind, er det jo for tidligt at sige noget om. Derimod kan man allerede nu

1 Således defineret af Bente Holmberg (s. 206) ovenfor det her citerede. 
konstatere at Dansk tager form lever op til forordets principper. Der er tale om god, forskningsbaseret formidling, der henvender sig både til sprogforskere ( $\mathrm{i}$ bind 1 især dog uden for deres primære forskningsfelt) og til andre sproginteresserede. Ind i mellem kan man nok støde på detaljer man synes kunne forbedres: Ting der kunne være udtrykt lidt klarere, ting man gerne ville have haft uddybet, karakteristikker der kunne præciseres. Men alt i alt er Dansk Sproghistorie kommet godt fra start. Jeg tror der er grund til at være fortrøstningsfuld og glæde sig til de kommende bind.

Asger gudiksen

Institut for nordiske studier og sprogvidenskab

Københavns Universitet

gudik@hum.ku.dk 


\section{LITTERATUR}

Bandle, O,K. Braunmüller, E.H. Jahr, A. Karker, H. Naumann \& U. Teleman. 2002-2005. The Nordic languages. An international handbook of the history of the North Germanic languages, bind 1-2. (Handbücher zur Sprach- und Kommunikationswissenschaft 22). Berlin: Walter de Gruyter.

Bennike, V \& M. Kristensen. 1898-1912. Kort over de danske folkemål med forklaringer. København: Gyldendal.

Borup, T.C. \& A. Sufi. 2014. Gade/dansk ordbog - en haindbog i ghettodansk. København: People’s Press.

Brink, L. \& J. Lund. 1975. Dansk, rigsmål. Lydudviklingen siden 1840 med sarligt henblik på sociolekterne $i$ Kobenhavn, bind 1-2. København: Gyldendal.

Hansen, E. \& L. Heltoft. 2011. Grammatik over det danske sprog. København: Det Danske Sprog- og Litteraturselskab.

Holmberg, B., B.O. Frederiksen \& H. Ruus (red.). 1989. Forskningsprofiler. Udgivet af Selskab for nordisk Filologi. København: Gyldendal.

Larsen, J., C. Lisse \& K.M. Nielsen (red.). 1965. Det danske sprogs udforskning i det 20. årbundrede. Udgivet af Selskab for nordisk Filologi. København: Gyldendal.

Skautrup, P. 1944-1970. Det danske sprogs historie, bind 1-4. København: Det Danske Sprog- og Litteraturselskab.

www.dansksproghistorie.dk (tilgået 15. september 2017).

www.dsl.dk (tilgået 15. september 2017). 